\title{
First Partnerships to Fight Tuberculosis
}

\section{Sanitize $E^{*}$ and Shengelia $\mathbf{R}$}

Tbilisi State Medical University, Department of History of Medicine and Bioethics, Georgia

${ }^{*}$ Corresponding author: Sanitize E, Tbilisi State Medical University, Department of History of Medicine and Bioethics, Georgia, Tel: 995 99329822; E-mail: ekasanikidze@yahoo.com

Received date: September 07, 2015, Accepted date: September 30, 2015, Published date: October 05, 2015

Copyright: @2015 Sanitize E. This is an open-access article distributed under the terms of the Creative Commons Attribution License, which permits unrestricted use, distribution, and reproduction in any medium, provided the original author and source are credited.

Keywords: Tuberculosis; Phthisis

\section{Introduction}

In the history of fight against $\mathrm{TB}$ last years are mentioned as acceleration of social activities, involvement of Civil Society Organizations (SCOs), former TB patients, their family members, popular persons to achieve changes in the anti TB policy-arise funding for better diagnostic and treatment methods, improve regulations, combat stigma and discrimination and protect human rights. Conferences, trainings, high level meetings, guides, recommendations, methodologies are dedicated to community involvement issues. But it appeared that social forms of fight against TB existed in the past and even anti TB organizations were founded in the second half of XIX century. It means that we should learn more about this experience and use approved historical methods to fight TB via community involvement and social mobilization.

\section{Problem}

Tuberculosis exists probably ever since pre-historic times. There is evidence that humans were affected by the disease from a time 4000 years ago. Skeletal remains of pre-historic humans from that time revealed signs of the disease. Tuberculosis destruction was also revealed in the bones of Egyptian mummies of 3000-2400 BC. Even in India and America, there are indications of the occurrence of tuberculosis around 2000 BC. Around 460 BC., Hippocrates identified "Phthisis" (Greek for wastage) as the most widespread disease of all times, which almost always resulted in death.

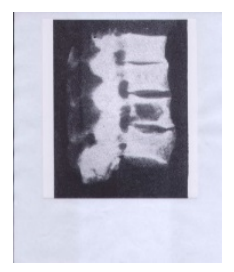

Figure 1: TB spondilitis, paleontological material- V-VI cc, BC, Georgia.

Tuberculosis is a virulent disease of the lungs. It had long been known and studied in Europe, where it went by several names, including phthisis, consumption, and "the white plague. [1]" Though it affected people of all ages and social classes, it became a leading killer of the urban poor, particularly after the 1850s. So, at the end of the nineteenth century, whole world, especially Europe and America earned tuberculosis (hereafter abbreviated TB) as a deadly and insidious disease. In an attempt to decrease tuberculosis mortality and control the disease, doctors and scientists undertook a number of initiatives to combat TB beginning in the late 1880s that continued through the mid-twentieth century, when antibiotics that effectively treated the disease were discovered.

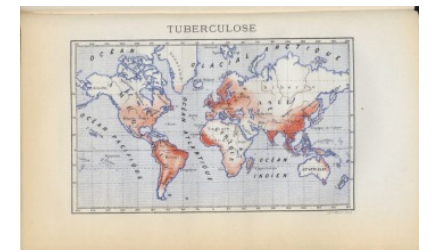

Figure 2: The map of TB epidemiology XIX cc -Poincaré, Émile Léon. Prophylaxie et géographie médicale :des principales maladies tributaires de l'hygiène. From the holdings of Center for the History of Medicine/Francis A. Countway Library of Medicine-Harvard Medical School.

These efforts constituted an anti-tuberculosis movement that can be defined as a sustained crusade to decrease TB mortality and eradicate the disease by voluntary health organizations, government agencies, charities, medical societies, doctors, and members of the public. They worked at the local, state, and national levels using a variety of methods, especially education that focused on preventing the spread of the disease.

Although TB had maintained a high mortality rate since the midnineteenth century, an active campaign to eradicate the disease did not begin until Robert Koch identified the bacillus that causes tuberculosis in 1882. That knowledge galvanized physicians and concerned citizens to unite to fight the disease in a worldwide anti-tuberculosis movement.

\section{Results of Review and Discussion}

\section{First anti TB organizations and their role to fight TB}

In Europe, national anti-tuberculosis efforts began as early as 1891 when France founded a national association. Germany followed suit in 1895 , Belgium in 1898, and Portugal and Italy in 1899. By the early twentieth century, the movement spread worldwide. Canada began a national anti-tuberculosis association in 1900, followed by Denmark and Australia in 1901, Sweden in 1904, Japan in 1908, and Norway and Russia in 1910. Britain's National Association for the Prevention of Tuberculosis began in 1898 with the goals of educating the public, opening $\mathrm{TB}$ facilities for the infected, and eradicating bovine tuberculosis. Britain's National Association for the Prevention of Tuberculosis began in 1898 with the goals of educating the public, opening TB facilities for the infected, and eradicating bovine tuberculosis. 
Page 2 of 5

So, France was one of the first countries, which started struggle against TB on the governmental and social levels.

In 1899 France Parliament commission to fight TB referred to meaning of public education. In 1900 the Special society for TB prevention via public education was created. (Societe de preservation contre la tuberculose per l'education populaire). Society published and distributed popular literature in various versions, organized public lectures, exhibitions of posters, tables, photos. The same actions were conducted by another anti TB organization the National Committee for TB prevention department of propaganda. They arranged popular presentations, used movies, exhibitions, posters and leaflets. Anti TB movement appeared to be so important, that French Medical Academy became to worry about possible panic among people and deepening of stigma. Nevertheless, first anti TB societies and partnerships were created and this process became irreversible.

In 1890-1891 special fliers with advices and recommendations for population and patients were published in Germany. (Ratschlage, Belehrugen, Merkblatter). The central committee of society for establishment of Public TB sanatorias (1895) conducted public readings and lectures, created TB museum. The Berlin Congress to fight TB (1899) considered their mission as to ensure population in the necessity of permanent fight against TB. In 1924, at the Phthisiologists congress in Coburg, Dr. Sell in his program entitled "TB and Fight against TB via soul arm" (Die Tuberkulose und ihre Bekampfung mit geistigen Waffen) emphasized that "sanitarian- educational work is the soul of Fight against TB" and called all professionals to be involved in this actions. Famous phthisiologist Brauening emphasized the meaning of patients and their family member's education and initiated organizing of "TB weeks" in schools.

\section{England}

Main reason for waging an anti-tuberculosis battle was to increase national efficiency in the economy and to maintain its Empire and world status. Contemporaries lamented the loss of life, but researched the cost of TB in terms of loss of workers in the economy and the cost of medical care. American motivations seem to have differed as physicians and anti-tuberculosis workers concentrated on stopping the tremendous loss of life due to tuberculosis and eliminating the public health threat that $\mathrm{TB}$ posed to American communities. The tuberculosis movement in the United States focused less on broadly improving society and the economy than it did on improving its collective health.

\section{USA}

After several preliminary meetings, a group of over 200 members, almost all of them doctors, formed the National Association for the Study and Prevention of Tuberculosis (NASPT) on June 6, 1904. The group raised money through membership dues as well as donations. The popular cause brought in gifts from the likes of John D. Rockefeller, and by 1905 the group was able to pay its Executive Secretary a $\$ 5,000$ salary to head the association from New York. The NASPT was the first group of its kind in the United States in that it was made up of volunteers dedicated to fighting one specific disease. The NASPT tried to convince legislators and public health departments to fund sanatoriums so that infected patients could be removed from the community before they spread the disease. In this era, drugs to fight tuberculosis had not yet been developed. The NASPT sponsored programs to educate the public about the disease, as early detection offered patients the best hope of survival. The group also raised money for medical care of indigent patients, as there was no national health insurance system [2].

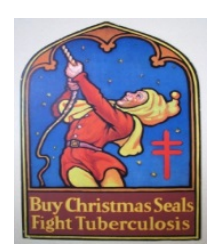

Figure 3: Christmas Seals-1910, NASPT, USA.

The NASPT had broad aims, but it needed more money to fund its programs. It began raising money through its Christmas Seals program in 1907. Emily P Bissell was responsible for the first successful Christmas Seals campaign. Bissell had heard of a successful project in Denmark to raise money for the care of tubercular children through the sale of special stamps.

With the permission of the Red Cross and the NASPT, Bissell herself drew the stamp, borrowed money to have 50,000 printed, and began selling them in Wilmington's main post office. The idea was for people to buy the special stamp and put it on their Christmas cards. It was not US postage but a means of raising money and also awareness. Bissell's campaign raised about $\$ 3,000$, enough money to preserve the tuberculosis shelter and to buy land for another, much modern tuberculosis hospital.

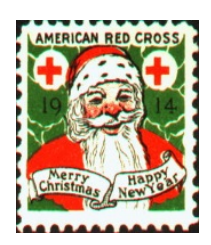

Figure 4: American Red Cross charity seals-1914.

The next year, the Red Cross sponsored a nationwide sale of Christmas Seals with a stamp designed by the renowned illustrator Howard Pyle. That sale brought in $\$ 135,000$. The NASPT took over the Christmas Seal sale from the Red Cross in 1910 and in 1919 began using as the seal's symbol the double-barred cross. The NASPT changed its name in 1918 to the National Tuberculosis Association (NTA), and in 1920 the group registered the double-barred cross as its trademark.

The NTA also had a medical arm, first called the American Sanatorium Association, and in 1939 taking the name the American Trudeau Society (after Dr. Edward Livingston Trudeau). The medical branch supported a variety of research into tuberculosis, set standards for treatment, and met annually to discuss new developments.

\section{Canada}

The Lung Association movement began in 1900 to control the spread of tuberculosis and provide better services for TB patients. Today, The Lung Association focuses on all issues that affect the ability of Canadians to breathe every day. The beginnings of an organized effort to deal with were made in Ontario in 1896, when Sir William 
Page 3 of 5

Gage founded the National Sanitarium Association for the purpose of building sanatoria for the treatment of tuberculosis [3].

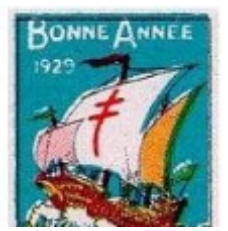

Figure 5: Canadian Lung Association charity stamp -1929.

Its first sanatorium, the Muskoka Cottage Hospital, which opened the following year, was a step in the right direction for sufferers from the disease, which previously had to seek sanatorium treatment outside the country. Two other organizations were formed in the next few years - The Toronto Association for the Prevention of Consumption and Other Forms of Tuberculosis in 1898, and the Ontario Association for the Prevention of Consumption and Other Forms of Tuberculosis in 1900-but it soon became apparent to concerned individuals that in order to achieve success the attack would have to be made on a national level. Dr Bryce, Dr Barrick, and the Reverend Eby, along with others who were interested, then took steps to organize the Canadian Association for the Prevention of Consumption and Other Forms of Tuberculosis.

The Commission for assessment of fight against TB methods was created in 1891 at the Public Health Care society In Russia. The Commission elaborated TB prevention measures. In $1900 \mathrm{~TB}$ commission of Pirogov's Society was also created. The meaning of education was realized on the governmental level and in 1903 "commission to fight tuberculosis" was established at the medical council of Ministry of Internal Affairs. It had relationships with Interanational TB council and was assessing the level of public medical education via special questionnaires. Famous Russian writer Chekhov was the first, who appealed to the decision makers and popular persons of Russia for participation in the opening of TB pension in Yalta for poor TB patients in 1899. Gorki, Tolstoy were first, who replied to this appeal. As a result, board "Yauslar" was opened in 1900. In 1910 The Russian Anti TB League to fight TB was established. It conducted wide range actions in the entire Russian Empire. Most popular were exhibitions. Blumental was the pioneer of arranging exhibitions and museums, including train, car exhibition at the North-west railway in 1912.

\section{Scandinavian Countries}

As the first of the Scandinavian countries, Norway, in 1900, passed a law to promote the fight against TB. The Danish parliament in 1897 included TB in the existing law on contagious diseases and in 1905 passed two laws particularly concerning TB. Small revisions in 1912 did not change the main characteristics of the Danish laws. Sweden legislated on TB in 1914 with important revisions in 1939. Like in many other parts of the world, also in Scandinavia bacteriology strengthened the perception that certain behaviors heightened the chances of infection: squalid living conditions, poor standards of nourishment, spitting, lack of fresh air. Extensive information campaigns were organized not least by voluntary organizations such as the National Anti-Tuberculosis Organizations. Informing people of how the disease spread and of what to do to minimize the danger of transmission meant appealing to the responsible and persuading or frightening the irresponsible to act according to certain rules. Information aimed to change unacceptable behavior and mobilize individual responsibility in the fight against disease. In this respect Swedish authorities made a monumental effort through the activities of hundreds of dispensaries.

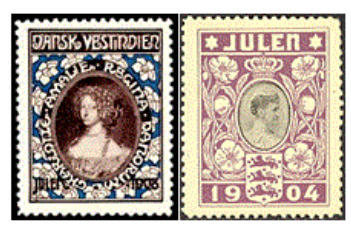

Figure 6: Norway TB charity seal-190.

In Norway and Denmark intensive lecturing campaigns and distribution of leaflets with advice against TB were part of this activity and nurses visited tubercular homes to inform and assist people in fighting the disease. In all three countries sanatoria were not only seen as treatment institutions, but also as offering the opportunity of educating the sick and hopefully have them spread knowledge of how to combat TB when they returned to their homes.

Both in information campaigns and in legislation, the poor and irresponsible were the main target groups. They were understood as the most important carriers and in need of information and education. People living in roomy and prosperous homes would not be submitted to the coercion applied to the poor. They were supposed to understand how to behave and be able to adopt the needed precautions without interference from public authorities. More popular and effective information campaign was "White flower Day."

\section{White Flower Day}

The idea of the White Flower Day was suggested for the first time in Scandinavian countries. The first White Flower Day was held in Sweden on May 1st of 1908. White flowers were sold as a symbol of fight with tuberculosis. That sale of white flowers attached people and brought a profit to anti-tuberculosis institutions and organizations. From Sweden, this custom was spread in Norway, Denmark, Germany, and in other European countries, including Russia [4].

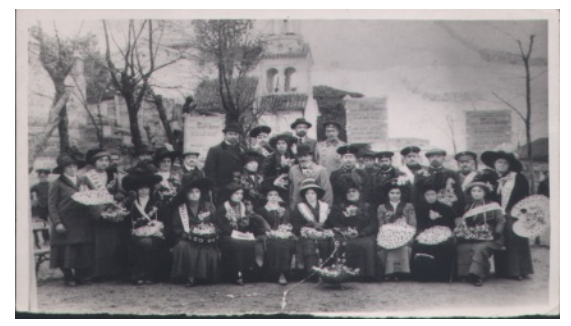

Figure 7: The Danish Christmas seal features the Danish queen Louise-1904.

Prior to the first White Flower Day in Russia, an enormous effort was made which resulted in foundation of All-Russian AntiTuberculosis League. One of the most important initiatives of AllRussian Anti-Tuberculosis League and its branches was initiation of the White Flower Day (or the Chamomile Day, or the Anti- 
Tuberculosis Day). The aims of the White Flower Days were antituberculosis educational work with the population and obtaining of funds for the League's activities. The first Anti-Tuberculosis Day was held in 1911. It was initiated by Vladimirov, a known figure in the League, and was dated for April 20th.

The program of the White Chamomile Day included two items: educational work and whip-round. The initiators of the Day believed that "a kind heart and an open hand" were the most essentials to fight TB. Whip-round was provided by the sale of artificial white flowers, arrangement of charitable performances, concerts, lotteries, etc.

As a rule, the White Chamomile Days were organized by antituberculosis societies or local branches of the League, which assigned special committees for this purposes. Quite often, the head of these committees was a trustee of the League or somebody of outstanding persons in the town, or representatives of local aristocracy or merchants, or wives of powerful administrators (governors).

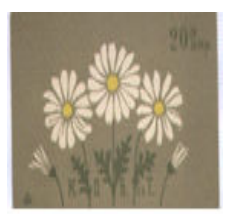

Figure 8: The "White Flower Day "(WFD) charity action in Russia, 1911.

Everyone tried to do what could to support that work. Doctors and teachers gave lectures in hospitals, clubs, at schools. Those lectures were quite popular. Famous scientists participated in the work: during the White Chamomile Days, they gave lectures and told people about tuberculosis, protective measures against tuberculosis.

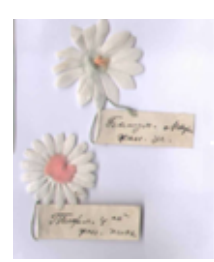

Figure 9: TB cards of Caucasian Society To Fight TB - Georgia, 1911.

In 1911, charitable donation throughout the country was made in the amount of about half a million rubles, and in 1912, about a million rubles. Income from donations was $70.1 \%$, and government allowance was only $0.3 \%$. Tsar's family made the largest private donations: in 1913 , donations were made in the amount of 10 thousand rubles.

The White Chamomile Days made a lot for further activity of branches of the League and local societies, including Caucasian society to fight TB in Georgia, where informational materials were provided on 4 languages [5].

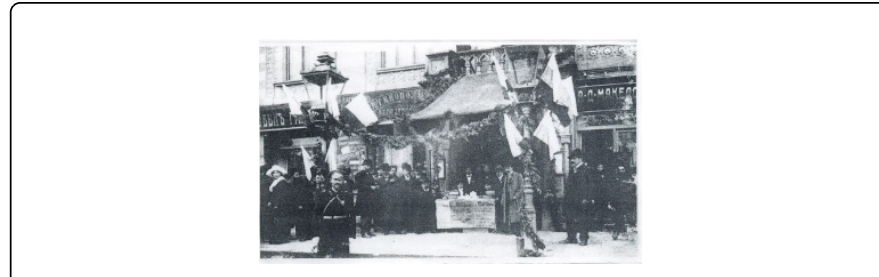

Figure 10: Chamomiles, made by Tbilisi and Batumi Gymnasium pupils-1911-1913 yy., Georgia.

Caucasian societies advocated government for creating facilities for medical and social assistance for TB patients. The money collected during the White Chamomile Days was used for arrangement of ambulance stations, hospitals, or for creation of funds for their construction. Those years, free hospitals were opened in large Russian cities, Caucasus. Cash benefits were given to needy persons for improvement of their living conditions. Many patients were supported with food stuffs.

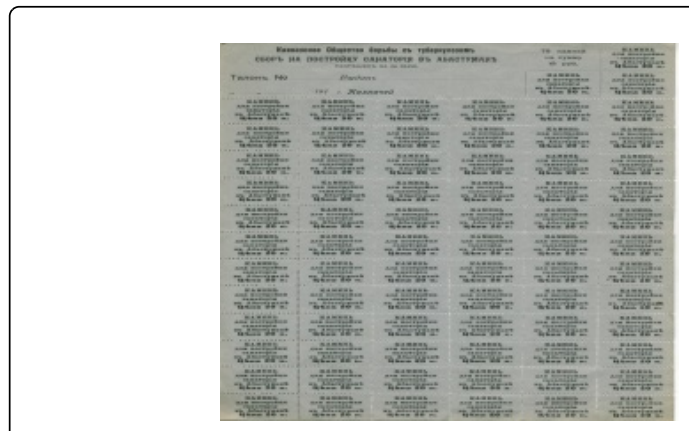

Figure 11: WFD charity action in Tbilisi-1911-1912 yy., Georgia.

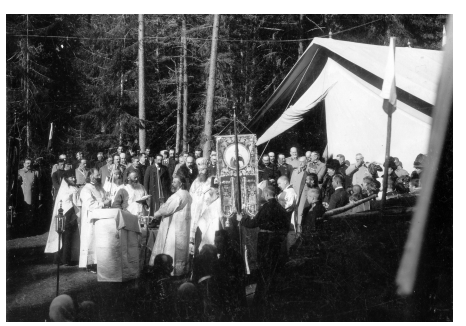

Figure 12: Special charity checks "Stone" to build TB sanatoria in Abastumani- Georgia, 1911.

After the October Revolution of 1917, People's Commissariat of Healthcare organized annual three days anti-tuberculosis actions during 1922-1928. That was renewal of the White Chamomile Day, to some extent. Those three days actions were intended to antituberculosis propaganda and whip-round. 
Page 5 of 5

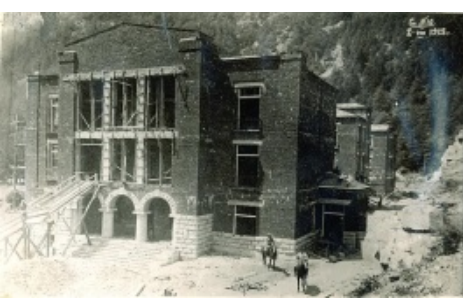

Figure 13: Blessing of foundation in Abastumani. Exarch Innocent and members of Caucasian Society to Fight TB-1911, Georgia.

Nowadays, considering a serious $\mathrm{TB}$ problem in many countries round the world, including Georgia, idea that traditions of the White Chamomile Day should be revived became active. In Georgia official renewal of White flower Day happened in 2003 by the initiative of "International Fund for Georgian Medicine" and Tbilisi State Medical University's History of Medicine Department [67].

Since 2005 the symbol of our anti TB information campaign is daisy and every World TB Day (WTBD) in Georgia is being arranged in the context of the White Flower Day.

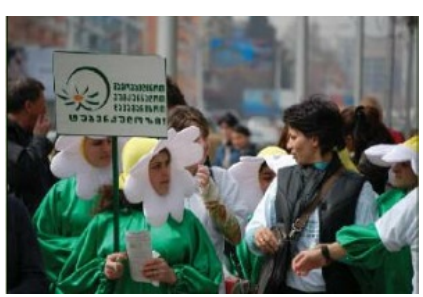

Figure 14: Construction of Sanatoria in Abastumani -1928, Georgia.

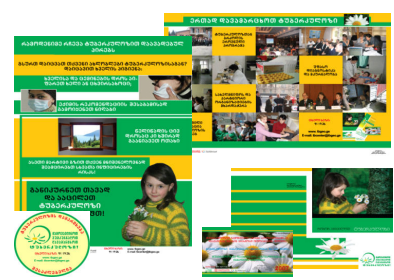

Figure 15: Modern TB informational campaign in Georgia-street action and printed materials 2006 .

\section{Conclusions}

Social forms of fight against TB still very important and needs to be strengthened and supported.

"White Flower Day" action, is a historical analogy of modern ACSM (Advocacy, communication and Social Mobilization) to fight TB, so our initiative is to renew this action and other effective historical methods of advocacy, communication and social mobilization to fight TB worldwide. We held it in Georgia and it proved to be really effective.

\section{Recommendation}

Establishment of international partnership "White Flower Movement" will provide legislative and social support of TB patients, involvement of civil society, popular persons and population in the fight against TB, and so-development of international advocacy for TB, which is very important to achieve needed funding and perfects regulations at international and local levels.

\section{References}

1. Gascoine KG (2010) Saving Children From The White Plague: The Marion County Tuberculosis Association's Crusade Against Tuberculosis, 1911-1936.

2. American Lung Association-Company Profile, Information, Business Description, History, Background Information on American Lung Association.

3. Tbilisi Medical Library archive materials-Protocols of Imperial "Caucasian Society of Doctors".

4. Bokuchava A (1968) History of Caucasian anti TB society In Georgia, Collected papers of scientific institute for Tuberculosis, 1968, Tbilisi, Georgia.

5. Richard L (2007) The Canadian Lung Association/Canadian Thoracic Society and tuberculosis prevention and control. Can Respir J 14: 427-. 431.

6. Tbilisi National Archive materials \#1875 (1864-1921).

7. Blom I (1935) Contagion and Cultural Perceptions of Accepted Behaviour Tuberculosis and Venereal Diseases in Scandinavia c.1900-c. 1950. 